\title{
Molecular Pathology of High-Grade Prostatic Intraepithelial Neoplasia: Challenges and Opportunities
}

\author{
Levent Trabzonlu, ${ }^{1}$ Ibrahim Kulac, ${ }^{2}$ Qizhi Zheng, ${ }^{1}$ Jessica L. Hicks, ${ }^{1}$ Michael C. Haffner, ${ }^{1,3}$ \\ William G. Nelson, ${ }^{1,3,4}$ Karen S. Sfanos, ${ }^{1,3,4}$ Onur Ertunc, ${ }^{1}$ Tamara L. Lotan, ${ }^{1,3}$ \\ Christopher M. Heaphy, ${ }^{1,3,4}$ Alan K. Meeker, ${ }^{1,3,4}$ Srinivasan Yegnasubramanian,, \\ and Angelo M. De Marzo ${ }^{1,3,4}$ \\ ${ }^{1}$ Department of Pathology, Johns Hopkins University School of Medicine, Baltimore, Maryland 21231 \\ ${ }^{2}$ Department of Pathology, Koc University School of Medicine, Istanbul 34010, Turkey \\ ${ }^{3}$ Sidney Kimmel Comprehensive Cancer Center, Johns Hopkins University School of Medicine, \\ Baltimore, Maryland 21287 \\ ${ }^{4}$ The Brady Urological Research Institute, Johns Hopkins University School of Medicine, Baltimore, \\ Maryland 21231 \\ Correspondence: ademarz@jhmi.edu
}

\begin{abstract}
A better understanding of the early stages of prostate cancer initiation, potentially arising from precursor lesions, may fuel development of powerful approaches for prostate cancer prevention or interception. The best-known candidate for such a precursor lesion has been referred to as high-grade prostatic intraepithelial neoplasia (HGPIN). Although there is significant evidence supporting the notion that such HGPIN lesions can give rise to invasive adenocarcinomas of the prostate, there are also numerous complicating considerations and evidence that cloud the picture in many instances. Notably, recent evidence has suggested that some fraction of such lesions that are morphologically consistent with HGPIN may actually be invasive carcinomas masquerading as HGPIN—a state that we term "postinvasive intraepithelial carcinoma" (PIC). Although the prevalence of such PIC lesions is not fully understood, this and other factors can confound the potential of identifying prostate precursors that can be targeted for disease prevention, interception, or treatment. Here, we review our current understanding of the morphological and molecular pathological features of prostate cancer precursor lesions.
\end{abstract}

$P^{r}$ rostate cancer is the most common noncutaneous cancer in males in Western countries, with 150,000 new cases and $\sim 25,000$ deaths projected to occur in the United States in 2018 (Siegel et al. 2018). Over the last two decades, the death rate from prostate cancer has decreased by $\sim 40 \%$ (Klotz 2018). This decrease appears to be the result, at least in part, of early detection by serum prostate-specific antigen (PSA) testing followed by aggressive treatment with curative

Editors: Michael M. Shen and Mark A. Rubin

Additional Perspectives on Prostate Cancer available at www.perspectivesinmedicine.org

Copyright (C) 2019 Cold Spring Harbor Laboratory Press; all rights reserved; doi: 10.1101/cshperspect.a030403

Cite this article as Cold Spring Harb Perspect Med 2019;9:a030403 
L. Trabzonlu et al.

intent of clinically localized disease, usually by either radical prostatectomy, radiation therapy, or combined radiation and hormonal treatment (Loeb et al. 2014; Schröder et al. 2014; Klotz 2018). Widespread implementation of serum PSA testing, however, led to many men being detected with low-grade cancers (Gleason score 6 or Grade Group 1 [Epstein et al. 2016]), and it is now recognized that the cancer cells within pure Gleason 6 tumors have exceedingly low capability of metastasizing (Ross et al. 2012; Donin et al. 2013; De Marzo and Epstein 2017). ${ }^{5}$ Yet, the majority of these men in the recent past have nevertheless been treated with aggressive regimens, which may result in significant side effects. And, these treatments in men with only Gleason score 6 tumors are now considered to represent overtreatment (Loeb et al. 2014; Klotz 2018). Over the last several years, an increasing use of active surveillance and watchful waiting appears to be mitigating this overtreatment problem, at least somewhat (Tosoian et al. 2016). In addition to potential overtreatment of low-grade/low-risk cancers, there are still significant problems encountered for men with intermediate and high-risk clinically localized prostate cancer (Gleason score 7 or higher). First, the radical treatments mentioned above are often inadequate because a significant fraction of those with intermediate- or high-risk clinically localized prostate cancer treated with curative intent manner experience cancer recurrence and disease-specific death (Silberstein et al. 2013). Furthermore, many men with high-risk localized disease are not offered curative procedures and may be undertreated (Silberstein et al. 2013; Bratt et al. 2015).

Given this unsatisfactory state of early detection of established prostate cancer using serum PSA testing/screening, there is great interest in developing strategies to prevent prostate cancer altogether. A highly successful model from oth-

\footnotetext{
${ }^{5}$ This does not mean that there is no potential for pure Gleason score 6 cancers to progress over time to more aggressive higher-grade lesions. Rather, it reflects evidence that at prostatectomy if only Gleason 6 disease is found in fully embedded and examined glands, then virtually none of these patients have concomitant lymph node metastases or develop recurrence or death owing to prostate cancer.
}

er cancer types involves the multistep carcinogenesis sequence in which there is a morphological spectrum of cellular/nuclear abnormalities that progress over time, ranging from normal, to mild atypia/dysplasia to severe atypia/carcinoma in situ (e.g., intraepithelial neoplasia [IEN]), before the development of invasive cancers with metastatic potential (O'Shaughnessy et al. 2002; Voltaggio et al. 2016). This timedependent sequence allows for screening of populations for the presence of cancer precursor lesions followed by effective treatments of those precursors to avoid the development of invasive cancers and prevent death and suffering from those diseases (O'Shaughnessy et al. 2002). Two major successful applications of this approach are the early detection and treatment of precursor lesions of the uterine cervix and colon/rectum. These success stories involved the systematic identification and removal of lesions visible to clinicians by either colposcopy (cervical high-grade squamous intraepithelial lesions) or colonoscopy (colorectal adenomatous polyps). Furthermore, these lesions were shown through decades of multidisciplinary studies to represent bona fide neoplastic precursors that often harbor many of the same driver molecular alterations as their invasive counterparts (e.g., high-risk human papillomavirus in high-grade cervical IENs and mutations in APC, RAS, and other relevant genes in adenomas that are associated with colorectal cancers). Other types of lesions, such as severe squamous dysplasia of the oral cavity and larynx, which may be seen clinically as leukoplakia and erythroplakia, are considered precursors to invasive squamous cell carcinoma (Voltaggio et al. 2016), and have similarly been investigated as potentially useful to identify, treat, and prevent subsequent invasive cancers from developing (Lippman and Hong 2002).

With these precedents for cancer prevention through identification and interception of cancer precursor lesions for multiple cancer types, there has been much effort and interest in identifying and understanding prostate cancer precursor lesions. Here, we will describe the current understanding of prostate cancer precursor lesions, considering their pathogenesis and mo- 
lecular mechanisms, relationship to invasive cancer, and considerations for prostate cancer prevention, interception, and/or treatment.

\section{PROBLEMS WITH THE PARADIGM OF "IDENTIFY AND ERADICATE THE PRECURSOR” IN PROSTATE CANCER PREVENTION}

Over the last few decades, many investigators have attempted to apply an "identify and eradicate the precursor" model to prevent invasive disease and metastases from prostate cancer by characterizing and treating prostatic precursor lesions. Most of the studies have focused on high-grade prostatic intraepithelial neoplasia (HGPIN) as the main direct precursor lesion of prostate cancer, and a great deal of evidence supports this supposition of HGPIN as the key precursor, at least for a significant fraction of cases (McNeal and Bostwick 1986; Bostwick et al. 1996, 2004, 2014; Bostwick and Cheng 2012; De Marzo et al. 2016). However, for a number of reasons, this approach to prostate cancer prevention by detecting HGPIN in high-risk populations, enrolling men in clinical trials, and treating HGPIN has presented unique obstacles that are largely absent in the models of precancer detection and treatment in the colon/ rectum, cervix, or head and neck. And, these difficulties may be important confounding elements leading to a general lack of efficacy in developing a chemoprevention strategy for prostate cancer using this approach (Bostwick et al. 2014; De Marzo et al. 2016; Cui et al. 2017).

One potential serious bias that negatively impacted prior prostate cancer prevention trials that enrolled high-risk patients harboring HGPIN is that of blinded sampling by typical ultrasound guided transrectal biopsies. The prostate traditionally has been the only organ in which men are biopsied for cancer using an approach in which the biopsy locations are not directed at suspected lesions seen by imaging or other modalities. This indicates that unless a tumor is relatively large and/or clearly palpable, biopsies are taken in a blinded, non-image-guided (albeit systematic) fashion, which results in many false-negatives for cancer. Thus, many of the earlier trials, which were often relatively small, and were conducted before multiparametric magnetic resonance imaging (mpMRI) becoming more prevalent, were hampered by the fact that upward of $20 \%-30 \%$ of patients classified as having isolated HGPIN at the start of the trial already harbored unsuspected invasive carcinoma. Given the fact that the primary end point of most of the trials was the prevalence of cancer assessed by an end-of-study or interim biopsy, this high misclassification rate had the potential to confound the overall results and conclusions of the studies. In addition, because of lack of sensitivity of blinded biopsies, which is known to miss $\sim 20 \%-30 \%$ of known cancers (Serefoglu et al. 2013), only $\sim 70 \%-80 \%$ of men that actually had cancer at the end of study would have been identified as such, with the others being misclassified as negative for cancer. Thus, sampling issues resulted in significant misclassification rates during evaluations for both entry into the studies, as well as the primary end point (cancer detection rates) of most of the studies (De Marzo et al. 2016). Although mpMRI (Duvnjak et al. 2018) is increasing in use, and in its ability to visualize high-grade/ relatively large prostate cancer lesions, there is currently no method to visualize HGPIN by imaging. Further, it is still the case that even with mpMRI, $\sim 7 \%-15 \%$ of moderate/high grade lesions (e.g., Gleason $3+4=7$ and above) may be missed if biopsies are only directed at MRI visible lesions and not also taken systematically (Thompson et al. 2016; Duvnjak et al. 2018).

\section{PROPOSED PROSTATE CANCER PRECURSORS, PROSTATIC INTRAEPITHELIAL NEOPLASIA (PIN) VERSUS POSTINVASIVE INTRAEPITHELIAL CARCINOMA (PIC)}

HGPIN is defined microscopically as the presence of cells in preexisting acini and ducts with nuclear and cytoplasmic features characteristic of invasive adenocarcinoma cells (Fig. 1) (Bostwick et al. 2014). These features include nuclear and nucleolar enlargement, with nucleolar enlargement in at least $10 \%$ of the cells (although it is often much higher than that) being the key 
L. Trabzonlu et al.
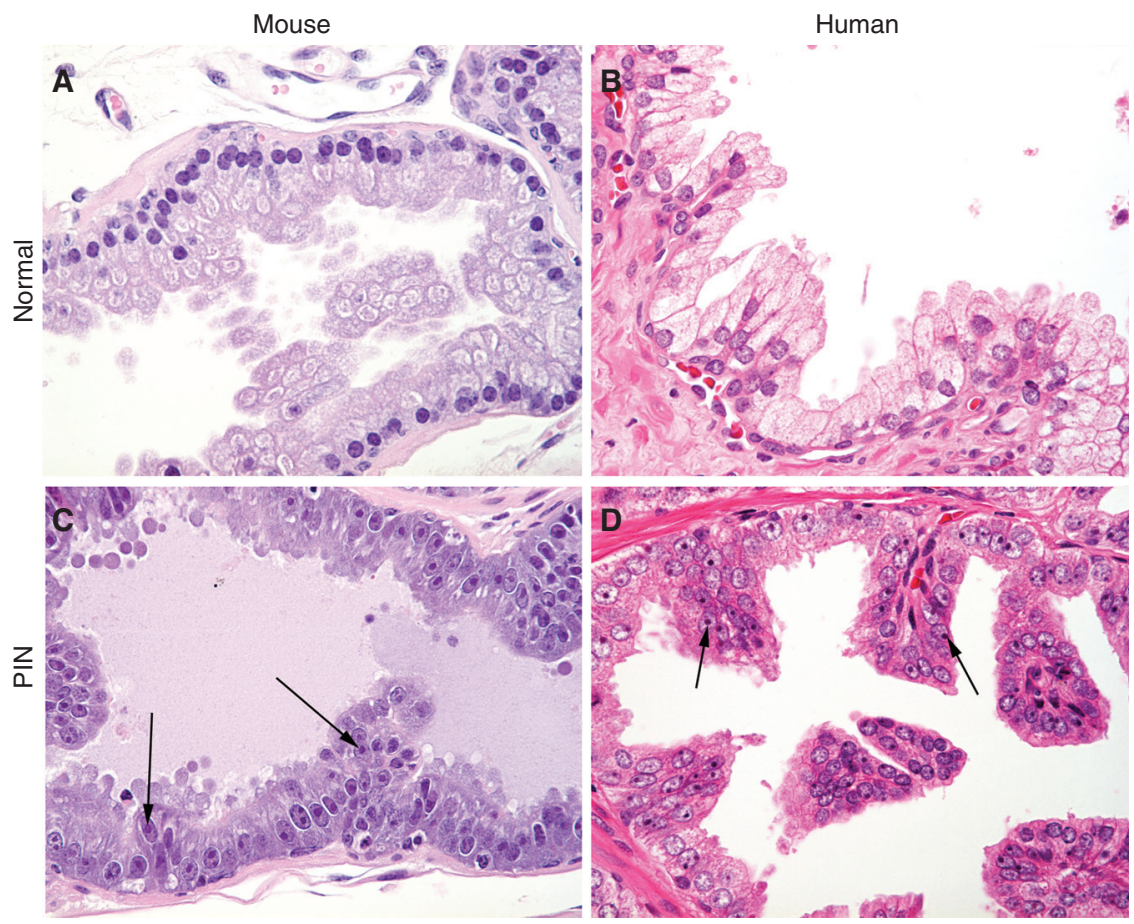

Figure 1. Morphological comparison of mouse and human normal appearing epithelium and prostatic intraepithelial neoplasia (PIN) lesions. All images were taken at the same magnification and processed similarly to allow direct comparisons $(400 \times)$. (A) Normal appearing mouse epithelium. (B) Normal appearing human prostate epithelium. (C) PIN lesion in a Lo-MYC mouse prostate. (D) PIN lesion in a human prostate. Arrows indicate enlarged nucleoli. (From Iwata et al. 2010; reprinted, with permission.)

histological hallmark of the diagnosis. Often, the involved glands/acini show cellular crowding and nuclear pseudostratification. There are a number of different architectural subtypes with the tufting subtype being the most common (Bostwick et al. 2014). Despite having reasonably well-defined histopathological criteria for HGPIN, and acceptable levels of interobserver reproducibility among experienced genitourinary pathologists (Epstein et al. 1995), another potential confounding factor for these trials, and many other prior studies on HGPIN, was raised recently by our group. Specifically, we have provided evidence supporting the hypothesis that some lesions that fulfill the histopathological criteria for the diagnosis of HGPIN actually represent a misclassification of invasive carcinoma as HGPIN (De Marzo et al. 2016; Haffner et al. 2016). This is not postulated to result from pathologist error but occurs because some lesions that qualify as histopathological HGPIN actually represent invasive carcinoma cells that masquerade as HGPIN cells. This can occur, for example, after invasion of prostate cancer cells into the stroma (the definition of carcinoma), in which the invading tumor cells eventually encounter benign glands/acini or ducts and then invade in a "retrograde" manner through the basement membrane back into those glands/ducts/acini (Fig. 2). This is followed by proliferation and spread along the acini, which can result in these invasive carcinoma cells mimicking the appearance of HGPIN (Fig. 2) (De Marzo et al. 2016; Haffner and Barbieri 2016; Haffner et al. 2016). This is an accepted pattern of spread in some other cancers, such as breast cancer (referred to as "cancerization of the lobules"), and is generally accepted as the primary manner for the development of most cases of intraductal carcinoma (IDCA) of the 


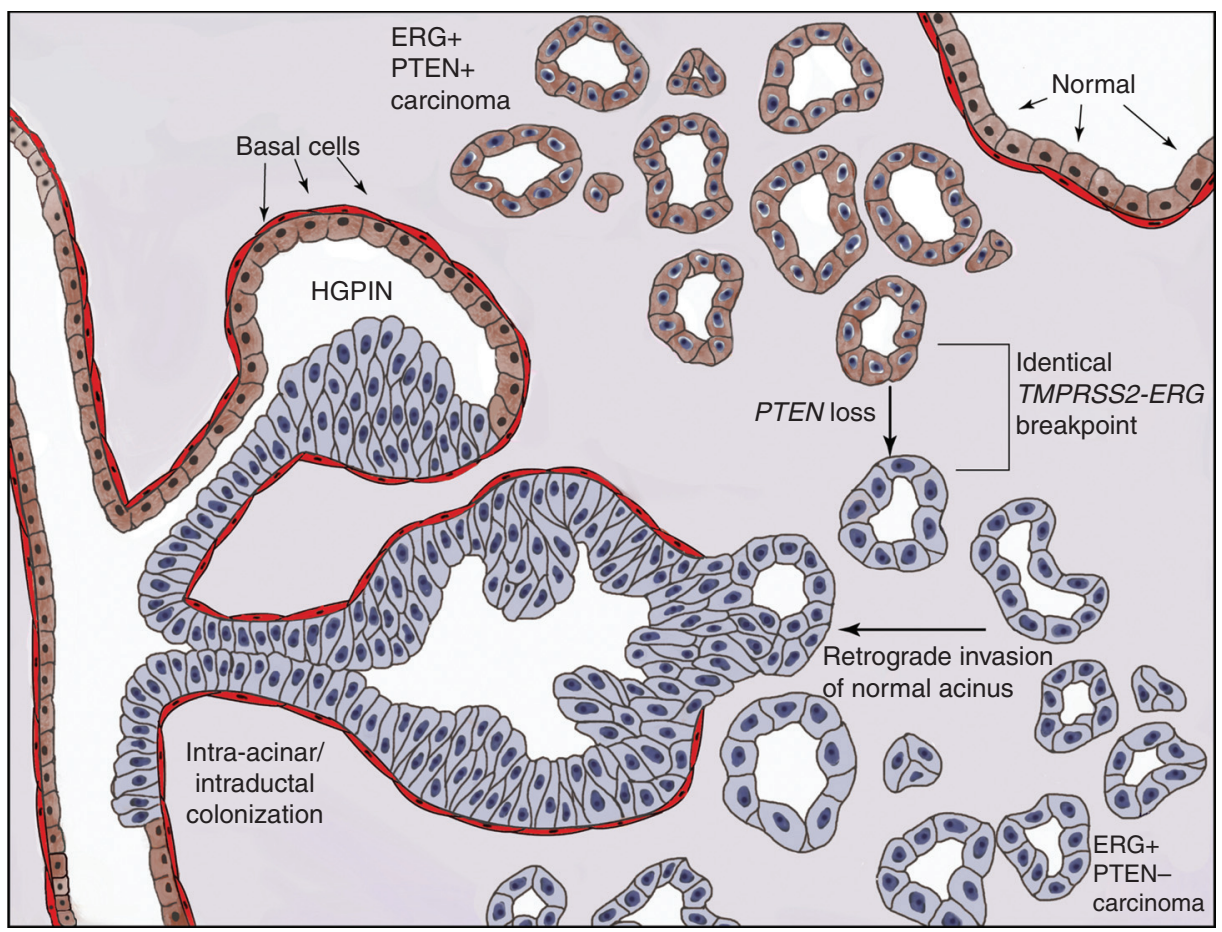

Figure 2. Proposed model of retrograde glandular colonization or postinvasive intraepithelial carcinoma (PIC). All invasive adenocarcinoma cells are ERG-positive caused by an early TMPRSS2-ERG fusion event, yet only part of the invasive adenocarcinoma shows PTEN loss and is therefore considered subclonal loss. In such an ERGpositive invasive adenocarcinoma with subclonal loss of PTEN, TMPRSS2-ERG genomic breakpoint analysis establishes the shared clonal origin of lesions. Subclonal PTEN loss can be used as a temporal vector. The observation that ERG-positive PTEN-negative cells populate normal acinar and ductal structures strongly suggests a retrograde spreading pattern of invasive carcinoma cells into benign glandular structures. PTEN-proficient normal prostate epithelial cells and adenocarcinoma are shown in brown. PTEN-deficient cells are drawn in gray. ERG overexpression is indicated by blue nuclei. Intact basal cells are highlighted in red. (From Haffner et al. 2016; reprinted, with permission.)

prostate, which is a lesion with very different clinical implications than HGPIN (Montironi et al. 2012; Böttcher et al. 2018). ${ }^{6}$ We term this phenomenon of carcinoma mimicking PIN as "postinvasive intraepithelial carcinoma" or PIC; we suspect that such PIClesions are more likely to be very near or adjacent to carcinoma than to be at a great distance from carcinoma (e.g., $>3 \mathrm{~mm}$ ).

To determine whether a given apparent HGPIN lesion represented a true precursor versus PIC, we used molecular tools involving both

${ }^{6}$ Although there does appear to be evolving data suggesting a spectrum of lesions ranging from HGPIN to atypical cribriform lesions to intraductal carcinoma (Shah et al. 2017).
ETS fusions and PTEN genomic alterations (Haffner et al. 2016). It has been established that when both ERG and PTEN are altered at the DNA level in a given prostate carcinoma, complete PTEN loss (e.g., homozygous deletion or some combination of deletion and mutation) occurs as a subclonal event after the more truncal $E R G$ gene fusion in $\sim 65 \%$ of the cases; it has not been seen in cases in which ETS gene fusions appear to occur after complete PTEN loss (Gumuskaya et al. 2013; Krohn et al. 2014). Clonality between the lesions was established using genomic breakpoints involving TMPRSS2:ERG, which have been shown to be unique, clonal, and a very early event in prostatic carcinogenesis 
L. Trabzonlu et al.

(Tomlins et al. 2005; Weier et al. 2013; Haffner et al. 2016). Then, in the same cases it was found that PTEN loss was present as a subclonal event in the invasive component and also in the histologically classified HGPIN components. A similar finding was present in IDCA in the same study. Although other explanations are possible, it was postulated that the simplest explanation for the combination of a partially PTEN-negative tumor and PTEN-negative PIN in the setting of an identical ERG breakpoint, was that very early during development of the carcinoma there was a TMPRSS2:ERG rearrangement event and that later during progression of the invasive carcinoma, there was a subclonal loss of both copies of PTEN. This was followed by retrograde invasion of cells that harbored the TMPRSS2: ERG fusion and subclonal PTEN loss into a benign gland. Proliferation of these cells within that gland then produced a lesion that mimicked HGPIN (Haffner et al. 2016). Because only a small number of cases were studied (Fig. 2) (Haffner et al. 2016), the frequency and extent to which this retrograde involvement or PIC of the prostate occurs is currently unknown. Clearly, to develop a more complete understanding of this issue, additional methods are needed, beyond those in which the cases require a mapped TMPRSS2:ERG fusion at the genomic DNA level along with subclonal PTEN loss.

The hypothesis that a fraction of lesions classifiable as HGPIN actually represent PIC raises another interesting question about prior molecular studies, beyond how it may confound the results of chemoprevention trials. Many of the earlier molecular-based studies that were used to ultimately build the conclusive case supporting HGPIN as the precursor to prostate cancer (see Bostwick et al. 1996, 2014), used the fact that HGPIN cells often shared similar/identical somatic DNA alterations as their nearby invasive lesions. However, a significant fraction of the results and conclusions reported using this approach, in which PIN lesions with similar genomic alterations were often directly adjacent or very near (e.g., within $1 \mathrm{~mm}$ ) to the invasive adenocarcinoma, could also be consistent with PIC. In other words, the reason that similar somatic DNA (genomic and epigenomic) alter- ations were found in adjacent HGPIN lesions, as in invasive carcinoma, is that at times the cells that composed the presumed HGPIN lesions were in fact the cancer cells mimicking PIN. In general, this scenario did not appear to be strongly considered in many of the original manuscripts, although Perner and colleagues raised this possibility in their study (Perner et al. 2007). In fact, even if it was considered, the methods used often would not have had the capability to distinguish between HGPIN versus PIC. To go even further, some molecular studies have shown that some lesions considered being HGPIN at times contained additional changes not found in the carcinoma (Sakr et al. 1994b; Emmert-Buck et al. 1995; Jenkins et al. 1997; Ruijter et al. 1999). These findings represent evidence that the lesions classified as HGPIN in some cases can be derived from the carcinoma, and not the other way around. This is not to indicate that there is no strong molecular evidence that PIN is the precursor, but rather, many of the morphological-based and molecular-based studies that were used to support the hypothesis could be re-interpreted differently to include the fact that some of these represented PIC and not HGPIN.

\section{MOLECULAR PATHOLOGY EVIDENCE THAT HGPIN IS A PRECURSOR}

In evolutionary biology, if one species is proposed to have evolved from another, one of the critical pieces of evidence is the discovery of "intermediate forms" in which investigators identify species harboring features intermediate between the precursor species and the presumed subsequent form. The reason many of the prior studies cannot firmly distinguish between HGPIN and PIC is in part related to the lack of evidence for an "intermediate form"; most studies simply cataloged the frequency of alterations in HGPIN and nearby carcinoma, such as the fraction of cases with $\mathrm{LOH}$ on chromosome $8 \mathrm{p}$ (or other loci) or the rate of chromosome $8 \mathrm{q}$ gain. Nevertheless, there are some studies that at least suggest that HGPIN may at times be intermediate in terms of somatic DNA alterations between normal and invasive carcinoma. Using 
High-Grade Prostatic Intraepithelial Neoplasia

two different microsatellite markers for $\mathrm{LOH}$ on chromosome $8 \mathrm{p}$ after needle dissection (of FFPE tissues), Häggman et al. (1997) found that invasive carcinoma and adjacent HGPIN shared loss of the same allele for the NEFL locus in 4 of 11 cases, but in the same cases there was $\mathrm{LOH}$ in the tumor only for the D9S87 locus. This suggests that, although some regions of loss are shared between adjacent carcinoma and HGPIN, the extent of chromosomal arm loss can be greater in carcinoma than in PIN in the same cases, which provides evidence that PIN was intermediate molecularly between normal and carcinoma. Emmert-Buck and colleagues (Emmert-Buck et al. 1995) reported a high rate of loss of one allele on chromosome 8p12 (using three microsatellite loci) in microdissected highgrade PIN and carcinoma (90\% in carcinoma and $63 \%$ in HGPIN), and in terms of the pattern of loss of the three different loci examined, a few cases of HGPIN had intermediate levels of loss. Cerveira et al. (2006) found that mRNA for TMPRSS2-ERG fusions could be detected in HGPIN lesions and nearby carcinomas, but that somatic copy number alterations (SCNAs) in these cases were only detected in the carcinoma and not in the HGPIN lesions, suggesting that HGPIN and carcinoma were clonally related and that, at least in some cases, TMPRSS2$E R G$ fusions can form in HGPIN lesions prior to invasion.

In another example, when examining the methylation state of the GSTP1 upstream regula- tory region, Nakayama and colleagues (Nakayama et al. 2003) found that carcinoma showed hypermethylation $\sim 90 \%$ of the time and HGPIN $\sim 70 \%$ of the time (see Fig. 3 ). This rate of hypermethylation in HGPIN was similar to a prior study (Brooks et al. 1998). In the study by Nakayama, two different methylation-specific PCR reactions were used in which both reactions shared a downstream primer, but one had a different upstream primer. Interestingly, in carcinoma it was more common for both reactions to be positive for hypermethylation of target CpGs than in some HGPIN lesions, which were more often positive with only one of the reactions. These results raised the possibility that the extent (or density) of CpG methylation in carcinoma lesions is often higher than in HGPIN, which would imply that HGPIN contained intermediate levels of hypermethylation between normal and adenocarcinoma. In subsequent work this indeed appears to be the case (Inoue et al. 2008; H. Inoue, A.M. De Marzo, W.G. Nelson, et al., in prep.). Interestingly, although occurring with a much reduced frequency $(\sim 6 \%)$, focal prostate atrophy lesions (which we have described as proliferative inflammatory atrophy and have posited as a precursor to HGPIN and at times directly to carcinoma) also showed hypermethylation, as compared with completely normal appearing epithelium, and in most cases this was positive for methylation with only one of the two PCR reactions (Nakayama et al. 2003).

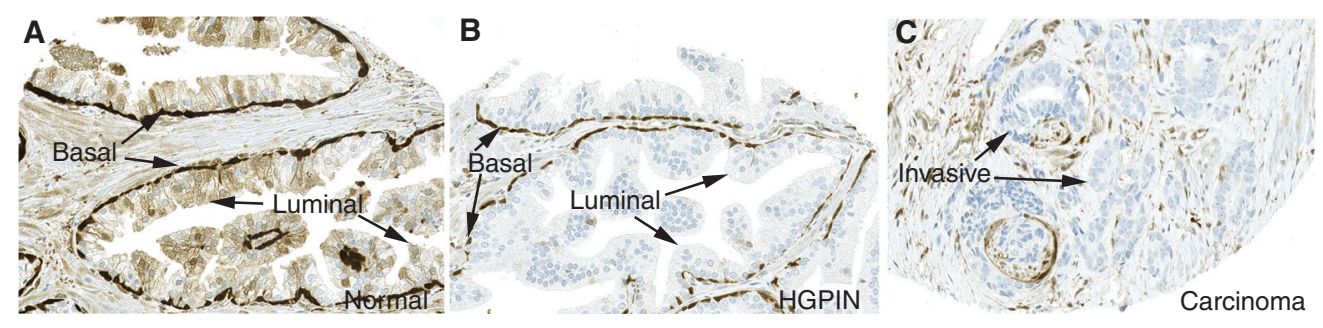

Figure 3. GSTP1 immunohistochemistry (IHC). For analytical validation, we have a series of prostate cancer cell lines with known GSTP1 status, and staining in them corresponds precisely with messenger RNA (mRNA) and prostate assessment by other means (e.g., RT-PCR and western blotting). These lines include LnCAP cells, which are negative for GSTP1, and PC3 cells, which are positive (Lee et al. 1994). IHC staining was performed using a mouse monoclonal antibody (Cell Signaling Technologies, \#3369) at 1:400 dilution on a Ventana DISCOVERY ULTRA Autostainer using the DISCOVERY anti-HQ HRP kit. Tissue type indicated in lower right of each image. $(A)$ Normal epithelium, $(B)$ high-grade PIN, and $(C)$ invasive adenocarcinoma. Original magnification, $\sim 200 \times$. 
L. Trabzonlu et al.

\section{RECENT MOLECULAR FINDINGS IN PIN USING NEXT-GENERATION SEQUENCING (NGS) APPROACHES}

More recently, Jung and colleagues (Jung et al. 2016) performed whole-exome sequencing on 20 regions of paired HGPIN and adenocarcinoma from six patients and reported SCNAs. Overall, there were some mutations and copy number alterations associated with both lesions, such as mutations in FOXA1 and CNAs in chromosome $1 \mathrm{q}$ and $8 \mathrm{q}$ gains. This suggests a clonal relationship in some of the cases. In this study, the number of total mutations and SCNAs associated with HGPIN were much less than in the invasive adenocarcinomas (Jung et al. 2016), and this implies that the HGPIN lesions analyzed did not appear to represent PIC. Also, mutations in SPOP, KDM6A, and KMT2D were found only in the carcinoma lesions and not in PIN. Chromosome $8 \mathrm{p}$ loss was either common to both, or, prostate cancer specific. One potential issue in analyzing this study, however, is that the investigators only used hematoxylin and eo$\sin (\mathrm{H} \& \mathrm{E})$ stained frozen sections to diagnose HGPIN from radical prostatectomy cases. We have found it to be very difficult to render a definitive diagnosis of HGPIN using frozen sections using $\mathrm{H} \& \mathrm{E}$ stained slides only, without additional in situ hybridization or immunohistochemical (IHC) studies (see Fig. 4). In fact, the images shown in the manuscript of the HGPIN lesions (Jung et al. 2016) do not allow one to be definitive that all of the cases indeed represented HGPIN, because a number of key diagnostic features, such as cell, nuclear and nucleolar enlargement were not readily identifiable.

Gerrin et al. (2016) performed a molecular case study from a single case of TMPRSS2:ERGpositive Gleason score 7 adenocarcinoma in which they used targeted deep sequencing of 6 HGPIN lesions that were nearby to carcinoma. Interestingly, all six HGPIN lesions shared the same TMPRSS2:ERG fusion. Further, 32 tumorspecific mutations, including 25 truncal mutations, were identified in the invasive carcinoma and only one of these was shared with the HGPIN lesions. The investigators concluded that the HGPIN and invasive carcinoma were clonally related, but that the HGPIN appeared to be relatively genomically stable. Although a number of prior studies have identified TMPRSS2:ERG gene fusions in HGPIN lesions (Tomlins et al. 2005; Perner et al. 2007; Furusato et al. 2010), only a single study that we are aware of examined isolated HGPIN lesions in surgical specimens without carcinoma (Morais et al. 2016). In this study, Morais and colleagues reported that $\sim 5 \%$ of HGPIN lesions showed ERG overexpression, indicative of an $E R G$ fusion gene. Together with the study by Gerrin and colleagues, these studies provide strong evidence that, at least in a limited number of cases, ERG gene fusions can occur in bone fide HGPIN lesions, before invasion. It is clear, however, that many more cases of HGPIN need to be examined with modern NGS-based genomic approaches to improve our ability to distinguish bona fide HGPIN from PIC and to better understand alterations that may lead to the transition of HGPIN to adenocarcinoma.

\section{HOW TO DEVELOP STRATEGIES FOR CHEMOPREVENTION OF PROSTATE CANCER USING PIN}

Although the above molecular arguments do not markedly undermine the hypothesis that HGPIN is the main precursor to invasive adenocarcinoma of the prostate, they do point out some deficiencies in the interpretation of the evidence used. In terms of the conclusion that PIN is the key precursor of invasive adenocarcinoma, the molecular and morphological data is not the only the body of evidence that may be interpreted in a different light with hindsight. For example, although some autopsy studies have found that the HGPIN appears to arise before invasive adenocarcinoma (Sánchez-Chapado et al. 2003), some do not; and this includes the two most highly cited studies that are often cited to indicate that PIN does arise before cancer (Sakr et al. 1994a, 1996; De Marzo et al. 2016).

Even if methods can be developed to definitively show which lesions classified as HGPIN represent precursors, the implementation of the "identify and eradicate the precursor" approach 


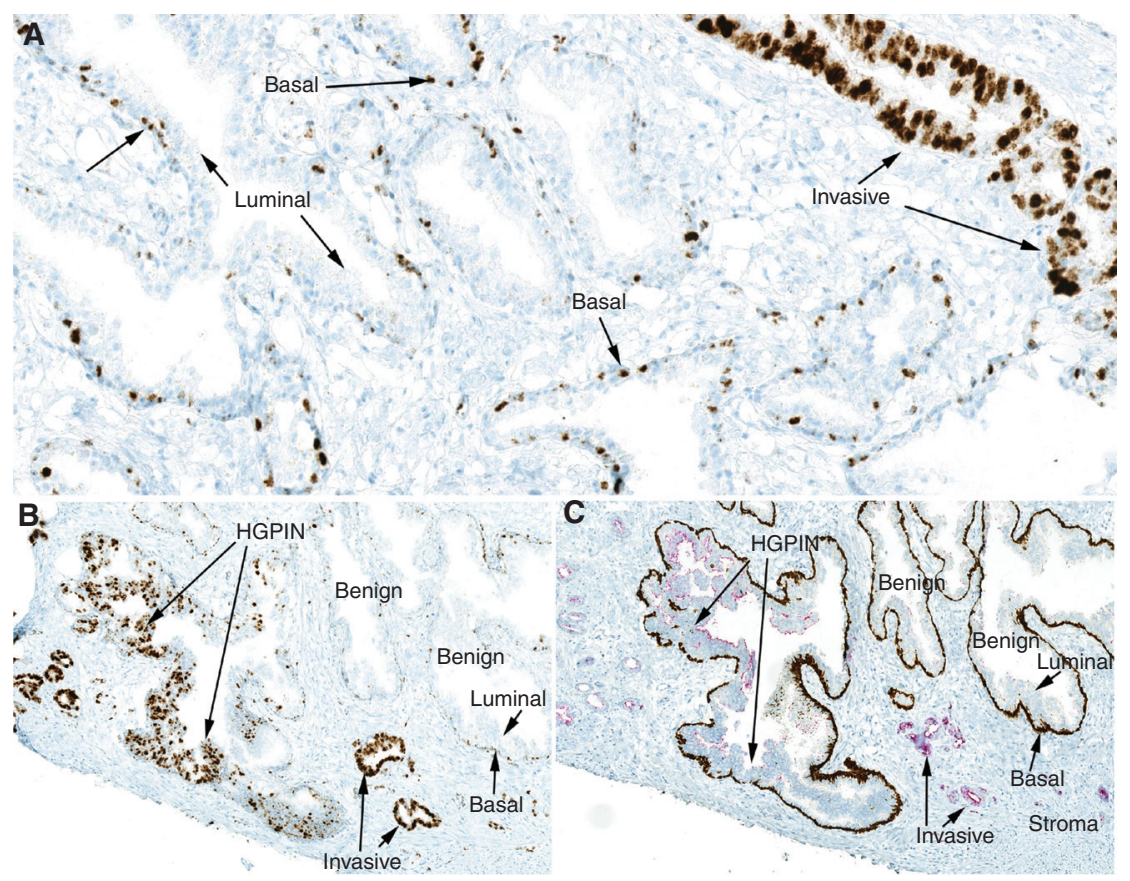

D

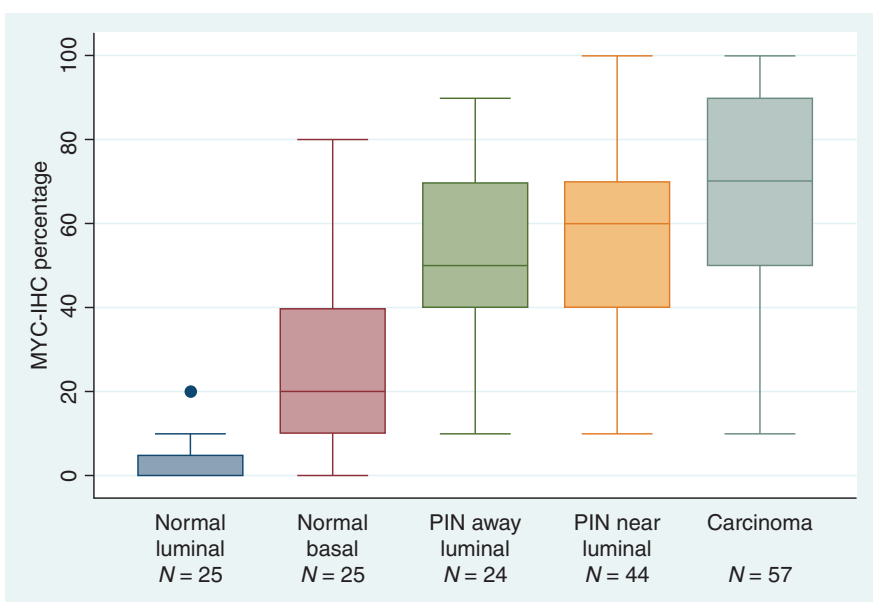

Figure 4. MYC immunohistochemistry (IHC) stains normal basal cells and is consistently increased in highgrade prostatic intraepithelial neoplasia (HGPIN) and adenocarcinoma. The antibody used for IHC staining for MYC was analytically validated previously (Gurel et al. 2008). Here, we used an updated protocol staining with the Ventana DISCOVERY ULTRA Autostainer, using the DISCOVERY anti-HQ HRP kit (details available on request) that results in an increased signal and less noise (e.g., increased signal-to-noise ratio). (A) This shows an example of using this protocol on a prostate cancer frozen section from a radical prostatectomy in which moderate intensity nuclear staining for MYC protein is present in a majority of basal cells. Also, there is strong intensity staining in invasive adenocarcinoma cells shown. Original magnification, $\sim 160 \times$. $(B)$ This shows HGPIN and invasive carcinoma staining for MYC protein by IHC. $(C)$ This shows an adjacent slide stained using the PIN4 cocktail IHC stain (McDaniel et al. 2014) for basal cells in brown (p63 and 34Be12) and $\alpha$ methylacyl Co-A racemase (AMACR) in red. HGPIN glands have basal cells and invasive carcinoma glands do not. There is also increased AMACR staining in the luminal HGPIN cells. Original magnification, $\sim 120 \times$. $(D)$ This shows quantification by visual estimation of the percentage of cells positive for each of the cell types shown. $N$ indicates the number of separate regions examined with that diagnosis that were present in 25 patient prostatectomy samples. The patients underwent surgery between 2016 and 2017 and had fresh frozen tumor tissues harvested; patient ages ranged from 50 to 73 . The Gleason score ranged from $3+4=7$ (Grade Group 2) to $4+5=9$ (Grade Group 5) and the pathological stage ranged from T2N0 to T3BN1. 
L. Trabzonlu et al.

for prostate cancer will remain exceedingly difficult without significant new developments in molecular imaging, because it is not feasible yet to localize and ablate PIN lesions by imaging in a manner similar to colorectal or cervical precursors. Although we cannot image HGPIN, mpMRI is improving at finding and ruling out large high-grade carcinomas and it may be possible in the near future to enroll patients with isolated HGPIN on biopsy and an otherwise negative mpMRI into clinical trials. However, without being able to localize the HGPIN, we will most likely need to develop a chemopreventive strategy based an improved understanding of the pathogenesis of the disease. Although HGPIN can be reduced in extent by androgen deprivation manipulations (Bostwick et al. 2014; Cui et al. 2017), it is unlikely that androgen deprivation approaches will be implemented for such a process, given the known problems (e.g., an excess of higher grade cases in the finasteride and dutasteride treatment groups ${ }^{7}$ ) with prostate cancer prevention trials using $5 \alpha$-reductase inhibitors (Thompson et al. 2003; Andriole et al. 2010) and the lack of cancer reduction in a recent randomized phase III trial of men with HGPIN by dutasteride (Milonas et al. 2017).

Also, ideally, we also need to develop a better understanding of which HGPIN lesions have potential to progress to clinically aggressive invasive adenocarcinomas and which do not (Haffner and Barbieri 2016). One can envision a future in which PIN will be found on biopsy and additional molecular testing on the PIN cells can be performed that indicate who is at high risk of developing aggressive invasive disease, or, whose apparent PIN lesion may actually represent already invasive carcinoma mimicking PIN (e.g., PIC). As a potential application of this, at least one study has suggested that the presence of a TMPRSS2-ERG fusion in isolated HGPIN is associated with a higher risk of finding cancer on a repeat biopsy (Park et al. 2014). ${ }^{8}$

\footnotetext{
${ }^{7}$ Whether $5 \alpha$-reductase inhibitors cause additional highgrade cancers or whether they result in a greater ability to detect them remains controversial (Redman et al. 2008).

${ }^{8}$ Although this could also relate to the fact that many PIN lesions with ETS fusions may represent PIC.
}

A pitfall with this approach is that many of the known drivers associated with aggressive disease generally do not occur in PIN lesions, or at least not commonly, and may be more associated with progression after invasive adenocarcinoma develops. An example of this is PTEN, which we and others have found as a subclonal event after invasive carcinomas have formed in a high fraction of cases (Gumuskaya et al. 2013; Jamaspishvili et al. 2018), and to occur exceedingly rarely or not at all in isolated HGPIN (Morais et al. 2015). Thus, it is not clear whether one can know with precision whether a given HGPIN lesion has aggressive malignant potential. A number of studies in prostate cancer have suggested, which is also the case in some other cancers, that the total burden of SCNAs is associated with disease aggressiveness and may be a biomarker of such (Taylor et al. 2010; Hieronymus et al. 2014). Therefore, future genome-wide studies of SCNAs may help predict which precursor HGPIN lesions may have a high propensity for development into aggressive disease.

In terms of determining the prevalence of HGPIN lesions that may be precursors to high-grade carcinomas, only few studies have been conducted. For example, most studies of "microcarcinomas," or those that are composed of only a small number of glands apparently budding off of HGPIN (McNeal et al. 1991), have used cases in which the carcinoma is consistent with Gleason score $3+3=6$, or Grade Group 1. Epstein and colleagues studied prostatectomy cases in which there were only relatively small foci of prostate cancer of relatively high grade (e.g., $>3+3=6$ or Grade Group 1), and reported that most cases had nearby HGPIN (Epstein et al. 1994). Cheng and colleagues mapped small prostate cancer lesions $(<0.5 \mathrm{~mL}$ in volume) and found that only $16 \%$ had any Gleason pattern 4 and only one such small lesion was a primary Gleason pattern 4 (Cheng et al. 2005). Taken together, there is very little information regarding whether some HGPIN lesions may be prone to develop high-grade versus low-grade adenocarcinoma and much more work needs to be performed in this area.

One approach to potentially enrich for patients with isolated HGPIN that may be at rela- 
tively high risk for development of aggressive invasive carcinomas, may be to perform germline testing for men with HGPIN and perform trials that enroll patients with germline DNA mutations in DNA repair pathway genes. The reason for this is that deleterious germline DNA-repair defects were recently found in $11.8 \%$ of patients with metastatic, castration-resistant prostate cancer (mCRPC), which was a significantly higher prevalence than that seen in men with localized prostate cancer (4.6\%) (Pritchard et al. 2016). At this time, however, it is only speculation to suggest patients with isolated HGPIN and such germline mutations would indeed be at higher risk.

Further, the malignant potential of a given HGPIN or carcinoma lesion may not only be present exclusively in the neoplastic cells but could also relate to alterations in the microenvironment, including innate and adaptive immune cells, fibroblasts, mesenchymal stem cells, endothelial cells, etc. In addition, changes in some of these such as the variability in telomere length in prostatic stromal cells may relate to environmental, lifestyle, or other factors such as cigarette smoking and obesity (Joshu et al. $2015,2017)$. Also, in terms of inclusiveness of men from different ancestral backgrounds, additional molecular pathology studies will need to be conducted in which higher numbers of men with African ancestry and of other heritages (e.g., Asian) need to be included, especially in studies of HGPIN. For example, evidence is now quite strong indicating that the frequency of TMPRSS2:ERG rearrangements in prostate cancer is less in men of African-American ancestry than in men of European ancestry (Sedarsky et al. 2018).

\section{WHAT CAUSES PIN?}

Our general lack of knowledge about HGPIN presented above strongly indicates that there is an important need to better understand what causes PIN and what molecular alterations drive its development and progression into cancers with lethal potential. In terms of what may be causing the early development of HGPIN and carcinoma, we have presented an evolving mod- el whereby inflammation, potentially caused by infections, diet, or both, might lead to proliferative lesions (e.g., proliferative inflammatory atrophy [PIA]) associated with alterations in the prostate microenvironment, including inflammatory cell infiltrates, that could evolve into HGPIN and or at times directly into small carcinoma lesions. PIA consists of a number of different morphological patterns of focal atrophy which are often associated with variable amounts of chronic, and at times acute, inflammation. A number of reviews and updates have been published describing this potential sequence (De Marzo et al. 2007; Sfanos and De Marzo 2012; Sfanos et al. 2017). This remains an active area of research and if the data further support a role for inflammation or infection in prostate cancer, then preventative strategies of the future may include approaches either to eradicate the inciting infectious agent (if still present), or to use anti-inflammatory agents, which have shown promise in other cancers.

\section{KEY MOLECULAR PATHWAY ALTERATIONS ACCOMPANYING THE DEVELOPMENT OF HGPIN}

In terms of molecular alterations found in HGPIN, a number of recent reviews, including our own have been published (Bostwick and Cheng 2012; Bostwick et al. 2014; De Marzo et al. 2016). Instead of being comprehensive in reviewing the molecular alterations, we will provide an update on three key alterations occurring in prostatic luminal cells (GSTP1 methylation, telomere shortening, and MYC overexpression) that occur extremely commonly in HGPIN and adenocarcinoma and suggest ways that these and other markers can be used to help determine the early ordering of events during the process of preneoplasia and early disease development. The determination of whether basal or luminal cells are the cell of origin for human prostate cancer remains an active area of investigation, with the weight of the evidence supporting a luminal cell in most cases (De Marzo et al. 2010; Goldstein et al. 2010a, 2010b; Taylor et al. 2012; Wang et al. 2013, 2014; Vander Griend et al. 2014; Lee and Shen 
L. Trabzonlu et al.

2015). In humans, the molecular somatic DNA alterations known to be associated with cancer, and that are able to be visualized in situ (either directly or by their consequences for expression), occur exclusively in luminal cells. These include those that occur relatively rarely, as in TMPRSS2-ERG gene fusions, or very commonly as in GSTP1 loss and telomere shortening. Although it is not completely possible to determine whether luminal cells are derived from basal cells in vivo in humans, there is compelling data in mice that at least at times luminal cells in the prostate can arise from basal cells (Lawson and Witte 2007; Toivanen et al. 2016). This suggests that even if the luminal cells are the "true" direct cell of origin in human HGPIN and adenocarcinoma, it is possible that these cells may have inherited a number of DNA alterations from a basal cell precursor that could provide a selective growth advantage when present in the progeny luminal cells.

GSTP1 encodes the Pi class of glutathione $S$-transferases and has been shown in dozens of studies to undergo highly frequent inactivation in prostate cancer by hypermethylation of sequences within its upstream regulatory $\mathrm{CpG}$ island (Lee et al. 1994; Nakayama et al. 2004; Valdés-Mora and Stirzaker 2018). A number of studies examining HGPIN have shown that hypermethylation of GSTP1 occurs in 70\% of HGPIN lesions, and as indicated above, the levels of methylation in HGPIN may be intermediate between normal and carcinoma (Nakayama et al. 2003). In both lung and skin carcinogenesis models, Gstp1/2 inactivation leads to additional tumor formation in the setting of carcinogen exposure (Henderson et al. 1998; Ritchie et al. 2007). The functional significance of GSTP1 silencing in prostate cancer is still under study, but one example is that it may be involved in protection against cytotoxicity and DNA adduct formation occurring in the setting of exposure to charred meat carcinogens (Nelson et al. 2001). In recent work that is still in process, it appears that in the right context, mouse Gstp1/2 (the equivalent of human GSTP1 is mouse Gstp1/2, which has two tandem copies of the gene) may function as an overt tumor suppressor in prostate cancer (Iwata et al. 2009) because crosses of mice with forced activation of MYC in the prostate to mice lacking Gstp1/2 resulted in increased tumorigenesis (Iwata et al. 2009).

Figure 3 shows normal prostate, HGPIN, and an invasive adenocarcinoma lesion after immunohistochemical staining against GSTP1 in human FFPE tissue microarray samples. In both the normal appearing epithelium and the HGPIN, there is strong staining in the basal epithelial cells, which has been previously extensively well characterized. Further, in most previous studies, we and others considered staining in normal appearing luminal cells (e.g., nonatrophy, non-PIN) to be essentially negative in most glands. However, using this updated IHC assay (see Fig. 3 legend), we find that normal luminal cells are often positive, albeit they are much less intensely stained than basal cells. Additional validity of the IHC assay is evident because, in the same cases, staining in the tumor cells and HGPIN luminal cells is completely negative (Fig. 3). This suggests that loss of GSTP1 protein in luminal cells may not simply be a bystander effect in cells that are already negative for GSTP1. Rather, it may be that even in addition to PIA (in which GSTP1 is highly induced) (De Marzo et al. 1999; Nakayama et al. 2003), normal luminal cells often express it at relatively low levels and loss of expression in such cells may have functional consequences. Interestingly, in the mouse prostate, the pattern of Gstp1/2 staining is different than in the human (Vaughn et al. 2011). For example, there is low-level positive staining in mouse prostate luminal cells (verified by negative staining under the same conditions using Gstp1/2 knockout mice) (Vaughn et al. 2011) without much difference in intensity between basal and luminal cells. Further, the low levels of Gstp1/2 protein found in normal mouse luminal cells above appear to have functional significance in tumor suppression.

The regulation of telomere length is a critical feature of human cells. As cells divide, telomeres progressively shorten, which can lead to replicative senescence and hence permanent cell cycle arrest. To undergo continuous self-renewal, cancer cells and stem cells must be able to maintain telomeres, and this is generally achieved by 
activating the telomerase enzyme (Kim et al. 1994). Although telomere maintenance can occur at times by the "alternative lengthening of telomeres" (ALT) mechanism in some cancer types, this is exceedingly rare in prostate cancer (Henson et al. 2002; Heaphy et al. 2011). Interestingly, human HGPIN cells have consistently short telomeres in the luminal compartment, compared with nearby normal appearing luminal and basal cells (Meeker et al. 2002; Vukovic et al. 2003). This is similar to adenocarcinoma, in that the vast majority of cases contain short telomeres, despite the somewhat paradoxical finding that most adenocarcinomas, as well as at least some PIN lesions (Koeneman et al. 1998), have increased telomerase activity compared with matched normal tissue (Sommerfeld et al. 1996; Meeker 2018). Interestingly, the RNA component of telomerase (hTR or TERC) is also overexpressed in human PIN and mouse PIN driven by human MYC and such overexpression has recently been found to be stimulated by MYC, suggesting that virtually all components of telomerase are up-regulated by MYC (Baena-Del Valle et al. 2018). For example, MYC regulation of the catalytic subunit (TERT) is well documented (Wang et al. 1998; Wu et al. 1999).

\section{MYC AS A CRITICAL DRIVER OF HGPIN AND PROSTATE CANCER}

In addition to improved methods to visualize GSTP1 protein, we have also recently enhanced our ability to visualize MYC by IHC using an automated staining system. Figure 4 shows that in normal basal cells there is variable yet frequent expression of MYC protein. In fact, although we have previously reported positive IHC staining for MYC protein in human basal cells, we have found using this new assay along with frozen tissue sections, that there is more consistent MYC-positive staining in normal basal cells, HGPIN and in adenocarcinoma lesions than seen previously. Using this approach, we estimated that the fraction of cells positive in normal appearing luminal cells (e.g., non-atrophy, non-PIN), underlying basal cells, HGPIN luminal cells and cancer. Figure $4 \mathrm{D}$ shows a stepwise increase in MYC protein staining in these cells types, and, in $\sim 90 \%-95 \%$ of cases there is clear MYC overexpression in PIN luminal cells (compared with normal luminal cells) and in adenocarcinoma lesions. Furthermore, using in situ hybridization for MYC messenger RNA (mRNA) (Baena-Del Valle et al. 2017), we also now report a highly similar pattern of staining for MYC mRNA and protein, with a strong positive correlation between the two in all of the cell/tissue types analyzed $\left(p<0.0001, r^{2}=0.774\right.$ by linear regression using STATA 15 for Windows, $N=175$ regions) (Fig. 5). Because MYC is known to be involved in self-renewal in a number of stem cell systems (Murphy et al. 2005), including embryonic stem cells and gastrointestinal stem cells, the fact that MYC is commonly expressed in a subset of normal prostate basal cells, suggests that MYC mRNA and protein expression in prostate basal cells may mark cells with stem cell properties.

Koh and colleagues have shown that in prostate cancer (Koh et al. 2010, 2011), as in many other cell types (Ji et al. 2011), MYC expression regulates nucleolar activity and a nucleolar and ribosomal program of gene expression. Coupled with the additional facts that nucleolar enlargement, accompanied by increases in RNA polymerase I activity (Guner et al. 2017), is the key diagnostic feature of HGPIN (see above), forced overexpression of MYC in the mouse prostate causes nucleolar enlargement and cellular proliferation (Ellwood-Yen et al. 2003; Iwata et al. 2010), and with the findings of the lack of known driver mutations in most human HGPIN studied to date (except perhaps for occasional ETS gene fusions, and the newly emerging findings on Gstp1/2 above), we submit that overexpression of MYC is a key driving event in the development of human HGPIN and likely in many (if not most) primary and many metastatic adenocarcinomas. If this is true, then it implies that if satisfactory inhibitors of MYC, or of MYC action, can be brought to the clinic (Goga et al. 2007; Brooks and Hurley 2010; Delmore et al. 2011; Mertz et al. 2011; Rebello et al. 2017), it is quite possible that these would be effective agents in reversing or treating HGPIN for prostate cancer prevention (given the caveats already 
L. Trabzonlu et al.
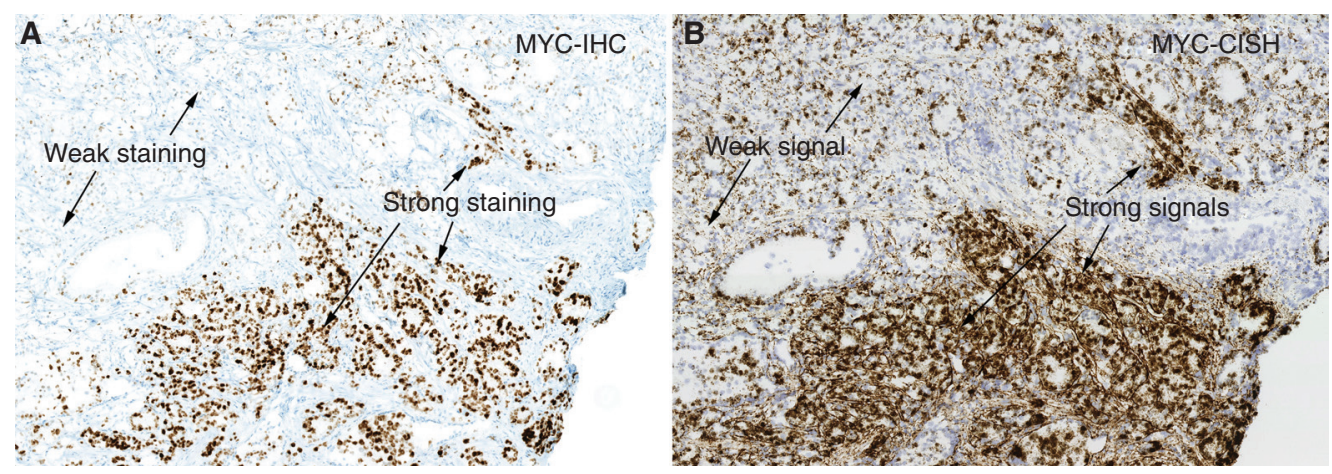

Figure 5. MYC protein by immunohistochemistry (IHC) generally correlates tightly with MYC messenger RNA (mRNA) by chromogenic in situ hybridization (CISH). (A) IHC performed in carcinoma as in Figure 4, showing marked increase staining in some parts of the tumor (strong staining), whereas other parts of the tumor show less intense staining (weak staining). (B) This regional heterogeneity of MYC protein staining is mirrored by a highly similar regional heterogeneity of MYC mRNA (method performed as described in Baena-Del Valle et al. 2017) levels using CISH. This highly similar pattern of regional heterogeneity in tumor cell staining for MYC protein and mRNA was a consistent finding across almost the great majority of cases.

described) and/or for treating established prostate cancers. Given that physiological MYC is involved in stem cell maintenance in some tissues, it is somewhat surprising (albeit gratifying), that systemically active dominant negative inhibitors of Myc in mice MYC can be safely tolerated (Jung et al. 2017).

Although MYC is commonly activated in HGPIN and prostate cancer (Gurel et al. 2008; Koh et al. 2010; Rebello et al. 2017), it is not clear in many cases what mechanisms drive such overexpression. Although gain of 8q24 centering on the MYC locus, does occur somewhat commonly in primary carcinoma and more commonly in CRPC (Koh et al. 2010), the definitions used for gain and/or amplification vary, making it somewhat difficult to correlate MYC expression and gene copy number. Although few studies have directly examined the correlation between MYC gene copy number and expression, in our own study, we did not find a correlation between MYC gene copy number by FISH and MYC protein levels (Gurel et al. 2008). Further, although MYC copy number increases have been reported in upward of $50 \%$ of HGPIN (Jenkins et al. 1997), we reported a lack of MYC gain by FISH in 25 HGPIN lesions (Bethel et al. 2006). Thus, despite many types of studies, including large scale genomic se- quencing-based studies (Barbieri et al. 2012; Grasso et al. 2012; Robinson et al. 2015; Cancer Genome Atlas Research Network 2015; Warrick and Tomlins 2018), we do not have a molecular explanation for MYC overexpression in most prostate cancers (and hence HGPIN). Clearly, additional work is needed both to better assess the correlation between MYC amplification and mRNA and protein levels on the one hand, and what molecular mechanisms may be driving MYC overexpression in HGPIN and carcinoma on the other.

\section{SUMMARY AND SPECULATION}

Human HGPIN remains the most likely precursor for many invasive adenocarcinomas of the prostate. Although there is a great deal of molecular evidence supporting this, a number of issues remain. First, it is not clear how often histologically identified PIN is actually a precursor or represents a postinvasive lesion. This, along with a general lack of knowledge about the cause of PIN and an inability to image the lesions, greatly hamper the development of chemopreventive strategies using men with HGPIN to enrich for trials of those at risk of aggressive prostate cancer. To better understand the fine molecular details of PIN lesions, much addi- 
tional work is needed. Three molecular alterations that are frequently present in HGPIN include GSTP1 methylation (and loss of protein expression), telomere shortening, and MYC overexpression. Because MYC overexpression is so common and its effects so pervasive on the biology of the cell, and because MYC activation alone can lead to the development of lesions resembling human HGPIN in mouse models, we submit that MYC overexpression is a critical driving force behind most human HGPIN lesions. Although in most cases we do not understand the mechanistic basis underlying MYC activation in PIN, we hypothesize/ speculate that if one could effectively identify HGPIN lesions in men before the development of invasive carcinoma and treat them with a future to be developed MYC inhibitor, it is likely that one could reverse PIN and prevent prostate cancer outright.

\section{ACKNOWLEDGMENTS}

This work was supported by the Sidney Kimmel Comprehensive Cancer Center at Johns Hopkins's Cancer Center Support Grant (National Institutes of Health/National Cancer Center [NIH/ $\mathrm{NCI}$ ] grant P30 CA006973), the NIH/NCI SPORE in Prostate Cancer P50 CA058236, the NIH/NCI U01 CA196390, and The Patrick C. Walsh Prostate Cancer Research Fund.

\section{REFERENCES}

Andriole GL, Bostwick DG, Brawley OW, Gomella LG, Marberger M, Montorsi F, Pettaway CA, Tammela TL, Teloken C, Tindall DJ, et al. 2010. Effect of dutasteride on the risk of prostate cancer. N Engl J Med 362: 11921202.

Baena-Del Valle JA, Zheng Q, Hicks JL, Fedor H, Trock BJ, Morrissey C, Corey E, Cornish TC, Sfanos KS, De Marzo AM. 2017. Rapid loss of RNA detection by in situ hybridization in stored tissue blocks and preservation by cold storage of unstained slides. Am J Clin Pathol 148: 398415.

Baena-Del Valle JA, Zheng Q, Esopi DM, Rubenstein M, Hubbard GK, Moncaliano MC, Hruszkewycz A, Vaghasia A, Yegnasubramanian S, Wheelan SJ, et al. 2018. MYC drives overexpression of telomerase RNA (hTR/TERC) in prostate cancer. J Pathol 244: 11-24.

Barbieri CE, Baca SC, Lawrence MS, Demichelis F, Blattner M, Theurillat J-P, White TA, Stojanov P, Van Allen E, Stransky N, et al. 2012. Exome sequencing identifies re- current SPOP, FOXA1 and MED12 mutations in prostate cancer. Nat Genet 44: 685-689.

Bethel CR, Faith D, Li X, Guan B, Hicks JL, Lan F, Jenkins RB, Bieberich CJ, De Marzo AM. 2006. Decreased NKX3.1 protein expression in focal prostatic atrophy, prostatic intraepithelial neoplasia, and adenocarcinoma: Association with Gleason score and chromosome 8p deletion. Cancer Res 66: 10683-10690.

Bostwick DG, Cheng L. 2012. Precursors of prostate cancer. Histopathology 60: 4-27.

Bostwick DG, Pacelli A, Lopez-Beltran A. 1996. Molecular biology of prostatic intraepithelial neoplasia. Prostate 29: 117-134.

Bostwick DG, Liu L, Brawer MK, Qian J. 2004. High-grade prostatic intraepithelial neoplasia. Rev Urol 6: 171-179.

Bostwick DG, C Liang, Meiers I. 2014. Neoplasm of the Prostate. In Urologic surgical pathology, 3rd ed. (ed. David LC, Bostwick G), pp. 410-531. Elsevier, Amsterdam.

Böttcher R, Kweldam CF, Livingstone J, Lalonde E, Yamaguchi TN, Huang V, Yousif F, Fraser M, Bristow RG, van der Kwast T, et al. 2018. Cribriform and intraductal prostate cancer are associated with increased genomic instability and distinct genomic alterations. BMC Cancer 18: 8 .

Bratt O, Folkvaljon Y, Hjälm Eriksson M, Akre O, Carlsson S, Drevin L, Franck Lissbrant I, Makarov D, Loeb S, Stattin P. 2015. Undertreatment of men in their seventies with high-risk nonmetastatic prostate cancer. Eur Urol 68: 5358 .

Brooks TA, Hurley LH. 2010. Targeting MYC expression through G-quadruplexes. Genes Cancer 1: 641-649.

Brooks JD, Weinstein M, Lin X, Sun Y, Pin SS, Bova GS, Epstein JI, Isaacs WB, Nelson WG. 1998. CG island methylation changes near the GSTP1 gene in prostatic intraepithelial neoplasia. Cancer Epidemiol Biomarkers Prev 7: 531-536.

Cancer Genome Atlas Research Network. 2015. The molecular taxonomy of primary prostate cancer. Cell 163: 1011-1025.

Cerveira N, Ribeiro FR, Peixoto A, Costa V, Henrique R, Jerónimo C, Teixeira MR. 2006. TMPRSS2-ERG gene fusion causing $E R G$ overexpression precedes chromosome copy number changes in prostate carcinomas and paired HGPIN lesions. Neoplasia 8: 826-832.

Cheng L, Jones TD, Pan C-X, Barbarin A, Eble JN, Koch MO. 2005. Anatomic distribution and pathologic characterization of small-volume prostate cancer $(<0.5 \mathrm{ml})$ in whole-mount prostatectomy specimens. Mod Pathol 18: 1022-1026.

Cui K, Li X, Du Y, Tang X, Arai S, Geng Y, Xi Y, Xu H, Zhou $\mathrm{Y}, \mathrm{Ma} \mathrm{W}$, et al. 2017. Chemoprevention of prostate cancer in men with high-grade prostatic intraepithelial neoplasia (HGPIN): A systematic review and adjusted indirect treatment comparison. Oncotarget 8: 36674-36684.

Delmore JE, Issa GC, Lemieux ME, Rahl PB, Shi J, Jacobs HM, Kastritis E, Gilpatrick T, Paranal RM, Qi J, et al. 2011. BET bromodomain inhibition as a therapeutic strategy to target c-Myc. Cell 146: 904-917.

De Marzo AM, Epstein JI. 2017. Gleason 6 Tumors Should Still Be Labeled as Cancer. In Active surveillance for localized prostate cancer. Current clinical urology (ed. Klotz L) pp. 41-52. Humana, New York. 
L. Trabzonlu et al.

De Marzo AM, Marchi VL, Epstein JI, Nelson WG. 1999 Proliferative inflammatory atrophy of the prostate: Implications for prostatic carcinogenesis. Am J Pathol 155: 1985-1992.

De Marzo AM, Platz EA, Sutcliffe S, Xu J, Grönberg H, Drake CG, Nakai Y, Isaacs WB, Nelson WG. 2007. Inflammation in prostate carcinogenesis. Nat Rev Cancer 7: 256269.

De Marzo AM, Nelson WG, Bieberich CJ, Yegnasubramanian S. 2010. Prostate cancer: New answers prompt new questions regarding cell of origin. Nat Rev Urol 7: 650652.

De Marzo AM, Haffner MC, Lotan TL, Yegnasubramanian S, Nelson WG. 2016. Premalignancy in prostate cancer: Rethinking what we know. Cancer Prev Res 9: 648-656.

Donin NM, Laze J, Zhou M, Ren Q, Lepor H. 2013. Gleason 6 prostate tumors diagnosed in the PSA era do not demonstrate the capacity for metastatic spread at the time of radical prostatectomy. Urology 82: 148-152.

Duvnjak P, Schulman AA, Holtz JN, Huang J, Polascik TJ, Gupta RT. 2018. Multiparametric prostate MR imaging: Impact on clinical staging and decision making. Radiol Clin North Am 56: 239-250.

Ellwood-Yen K, Graeber TG, Wongvipat J, Iruela-Arispe ML, Zhang J, Matusik R, Thomas GV, Sawyers CL. 2003. Myc-driven murine prostate cancer shares molecular features with human prostate tumors. Cancer Cell 4: 223-238.

Emmert-Buck MR, Vocke CD, Pozzatti RO, Duray PH, Jennings SB, Florence CD, Zhuang Z, Bostwick DG, Liotta LA, Linehan WM. 1995. Allelic loss on chromosome 8 p12-21 in microdissected prostatic intraepithelial neoplasia. Cancer Res 55: 2959-2962.

Epstein JI, Carmichael MJ, Partin AW, Walsh PC. 1994 Small high grade adenocarcinoma of the prostate in radical prostatectomy specimens performed for nonpalpable disease: Pathogenetic and clinical implications. J Urol 151: 1587-1592

Epstein JI, Grignon DJ, Humphrey PA, McNeal JE, Sesterhenn IA, Troncoso P, Wheeler TM. 1995. Interobserver reproducibility in the diagnosis of prostatic intraepithelial neoplasia. Am J Surg Pathol 19: 873-886.

Epstein JI, Egevad L, Amin MB, Delahunt B, Srigley JR, Humphrey PA, Committee G, et al. 2016. The 2014 International Society of Urological Pathology (ISUP) consensus conference on Gleason grading of prostatic carcinoma: Definition of grading patterns and proposal for a new grading system. Am J Surg Pathol 40: 244-252.

Furusato B, Tan S-H, Young D, Dobi A, Sun C, Mohamed AA, Thangapazham R, Chen Y, McMaster G, Sreenath T, et al. 2010. ERG oncoprotein expression in prostate cancer: Clonal progression of ERG-positive tumor cells and potential for ERG-based stratification. Prostate Cancer Prostatic Dis 13: 228-237.

Gerrin SJ, Sowalsky AG, Balk SP, Ye H. 2016. Mutation profiling indicates high grade prostatic intraepithelial neoplasia as distant precursors of adjacent invasive prostatic adenocarcinoma. Prostate 76: 1227-1236.

Goga A, Yang D, Tward AD, Morgan DO, Bishop JM. 2007. Inhibition of CDK1 as a potential therapy for tumors over-expressing MYC. Nat Med 13: 820-827.
Goldstein AS, Huang J, Guo C, Garraway IP, Witte ON. 2010a. Identification of a cell of origin for human prostate cancer. Science 329: 568-571.

Goldstein AS, Stoyanova T, Witte ON. 2010b. Primitive origins of prostate cancer: In vivo evidence for prostateregenerating cells and prostate cancer-initiating cells. Mol Oncol 4: 385-396.

Grasso CS, Wu Y-M, Robinson DR, Cao X, Dhanasekaran SM, Khan AP, Quist MJ, Jing X, Lonigro RJ, Brenner JC, et al. 2012. The mutational landscape of lethal castrationresistant prostate cancer. Nature 487: 239-243.

Gumuskaya B, Gurel B, Fedor H, Tan H-L, Weier CA, Hicks IL, Haffner MC, Lotan TL, De Marzo AM. 2013. Assessing the order of critical alterations in prostate cancer development and progression by IHC: Further evidence that PTEN loss occurs subsequent to $E R G$ gene fusion. Prostate Cancer Prostatic Dis 16: 209-215.

Guner G, Sirajuddin P, Zheng Q, Bai B, Brodie A, Liu H, Af Hällström T, Kulac I, Laiho M, De Marzo AM. 2017. Novel assay to detect RNA polymerase I activity in vivo. Mol Cancer Res 15: 577-584.

Gurel B, Iwata T, Koh CM, Jenkins RB, Lan F, Van Dang C, Hicks JL, Morgan J, Cornish TC, Sutcliffe S, et al. 2008. Nuclear MYC protein overexpression is an early alteration in human prostate carcinogenesis. Mod Pathol 21: 1156-1167.

Haffner MC, Barbieri CE. 2016. Shifting paradigms for highgrade prostatic intraepithelial neoplasia. Eur Urol 69: 831-833.

Haffner MC, Weier C, Xu MM, Vaghasia A, Gürel B, Gümüşkaya B, Esopi DM, Fedor H, Tan H-L, Kulac I, et al. 2016. Molecular evidence that invasive adenocarcinoma can mimic prostatic intraepithelial neoplasia (PIN) and intraductal carcinoma through retrograde glandular colonization. J Pathol 238: 31-41.

Häggman MJ, Wojno KJ, Pearsall CP, Macoska JA. 1997. Allelic loss of $8 \mathrm{p}$ sequences in prostatic intraepithelial neoplasia and carcinoma. Urology 50: 643-647.

Heaphy CM, Subhawong AP, Hong S-M, Goggins MG, Montgomery EA, Gabrielson E, Netto GJ, Epstein JI, Lo$\tan$ TL, Westra WH, et al. 2011. Prevalence of the alternative lengthening of telomeres telomere maintenance mechanism in human cancer subtypes. Am J Pathol 179: $1608-1615$.

Henderson CJ, Smith AG, Ure J, Brown K, Bacon EJ, Wolf CR. 1998. Increased skin tumorigenesis in mice lacking pi class glutathione S-transferases. Proc Natl Acad Sci 95: 5275-5280.

Henson JD, Neumann AA, Yeager TR, Reddel RR. 2002. Alternative lengthening of telomeres in mammalian cells. Oncogene 21: 598-610.

Hieronymus H, Schultz N, Gopalan A, Carver BS, Chang MT, Xiao Y, Heguy A, Huberman K, Bernstein M, Assel $\mathrm{M}$, et al. 2014. Copy number alteration burden predicts prostate cancer relapse. Proc Natl Acad Sci 111: 1113911144.

Inoue $\mathrm{H}$, Platz E, Nakai Y, Fedor H, Nelson W, Yegnasubramanian S, De Marzo A. 2008. Mapping of DNA methylation status of GSTP1 CpG island in human prostate tissue. Cancer Res 68: 4281-4281.

Iwata T, Schultz D, Vaughn M, Yegnasubramanian S, Nelson WG, De Marzo AM. 2009. Glutathione S-transferase pi 
(gstp1) deficiency accelerates prostate carcinogenesis in the Lo-myc mouse. J Urol 181: 183-184.

Iwata T, Schultz D, Hicks J, Hubbard GK, Mutton LN, Lotan TL, Bethel C, Lotz MT, Yegnasubramanian S, Nelson WG, et al. 2010. MYC overexpression induces prostatic intraepithelial neoplasia and loss of $\mathrm{Nkx} 3.1$ in mouse luminal epithelial cells. PLoS ONE 5: e9427.

Jamaspishvili T, Berman DM, Ross AE, Scher HI, De Marzo AM, Squire JA, Lotan TL. 2018. Clinical implications of PTEN loss in prostate cancer. Nat Rev Urol 15: 222-234.

Jenkins RB, Qian J, Lieber MM, Bostwick DG. 1997. Detection of c-myc oncogene amplification and chromosomal anomalies in metastatic prostatic carcinoma by fluorescence in situ hybridization. Cancer Res 57: 524-531.

Ji H, Wu G, Zhan X, Nolan A, Koh C, De Marzo A, Doan HM, Fan J, Cheadle C, Fallahi M, et al. 2011. Cell-type independent MYC target genes reveal a primordial signature involved in biomass accumulation. PLOS ONE 6: e26057.

Joshu CE, Peskoe SB, Heaphy CM, Kenfield SA, Van Blarigan EL, Mucci LA, Giovannucci EL, Stampfer MJ, Yoon G, Lee TK, et al. 2015. Prediagnostic obesity and physical inactivity are associated with shorter telomere length in prostate stromal cells. Cancer Prev Res 8: 737-742.

Joshu CE, Peskoe SB, Heaphy CM, Kenfield SA, Mucci LA, Giovannucci EL, Stampfer MJ, Yoon G, Lee TK, Hicks JL et al. 2017. Current or recent smoking is associated with more variable telomere length in prostate stromal cells and prostate cancer cells. Prostate doi: 10.1002/ pros. 23462.

Jung S-H, Shin S, Kim MS, Baek I-P, Lee JY, Lee SH, Kim TM, Lee SH, Chung Y-J. 2016. Genetic progression of high grade prostatic intraepithelial neoplasia to prostate cancer. Eur Urol 69: 823-830.

Jung LA, Gebhardt A, Koelmel W, Ade CP, Walz S, Kuper J, von Eyss B, Letschert S, Redel C, d'Artista L, et al. 2017. OmoMYC blunts promoter invasion by oncogenic MYC to inhibit gene expression characteristic of MYC-dependent tumors. Oncogene 36: 1911-1924.

Kim NW, Piatyszek MA, Prowse KR, Harley CB, West MD, Ho PL, Coviello GM, Wright WE, Weinrich SL, Shay JW. 1994. Specific association of human telomerase activity with immortal cells and cancer. Science 266: 2011-2015.

Klotz L. 2018. Cancer overdiagnosis and overtreatment In Active surveillance for localized prostate cancer, Current clinical urology (ed. Klotz L), pp. 1-8. Humana, New York.

Koeneman KS, Pan CX, Jin JK, Pyle JM III, Flanigan RC, Shankey TV, Diaz MO. 1998. Telomerase activity, telomere length, and DNA ploidy in prostatic intraepithelial neoplasia (PIN). J Urol 160: 1533-1539.

Koh CM, Bieberich CJ, Dang CV, Nelson WG, Yegnasubramanian S, De Marzo AM. 2010. MYC and prostate cancer. Genes Cancer 1: 617-628.

Koh CM, Gurel B, Sutcliffe S, Aryee MJ, Schultz D, Iwata T, Uemura M, Zeller KI, Anele U, Zheng Q, et al. 2011. Alterations in nucleolar structure and gene expression programs in prostatic neoplasia are driven by the MYC oncogene. Am J Pathol 178: 1824-1834.

Krohn A, Freudenthaler F, Harasimowicz S, Kluth M, Fuchs S, Burkhardt L, Stahl P, C Tsourlakis M, Bauer M, Tennstedt P, et al. 2014. Heterogeneity and chronology of
High-Grade Prostatic Intraepithelial Neoplasia

PTEN deletion and ERG fusion in prostate cancer. Mod Pathol 27: 1612-1620.

Lawson DA, Witte ON. 2007. Stem cells in prostate cancer initiation and progression. J Clin Invest 117: 2044-2050.

Lee SH, Shen MM. 2015. Cell types of origin for prostate cancer. Curr Opin Cell Biol 37: 35-41.

Lee WH, Morton RA, Epstein JI, Brooks JD, Campbell PA, Bova GS, Hsieh WS, Isaacs WB, Nelson WG. 1994. Cytidine methylation of regulatory sequences near the pi-class glutathione $S$-transferase gene accompanies human prostatic carcinogenesis. Proc Natl Acad Sci 91: 11733-11737.

Lippman SM, Hong WK. 2002. Cancer prevention by delay. Commentary re: J. A. O'Shaughnessy, et al., Treatment and prevention of intraepithelial neoplasia: An important target for accelerated new agent development. Clin Cancer Res 8: 314-346, 2002. Clin Cancer Res 8: 305-313.

Loeb S, Bjurlin MA, Nicholson J, Tammela TL, Penson DF, Carter HB, Carroll P, Etzioni R. 2014. Overdiagnosis and overtreatment of prostate cancer. Eur Urol 65: 1046-1055.

McDaniel AS, Chinnaiyan AM, Siddiqui J, McKenney JK Mehra R. 2014. Immunohistochemical staining characteristics of nephrogenic adenoma using the PIN-4 cocktail (p63, AMACR, and CK903) and GATA-3. Am J Surg Pathol 38: 1664-1671.

McNeal JE, Bostwick DG. 1986. Intraductal dysplasia: A premalignant lesion of the prostate. Hum Pathol 17: 6471.

McNeal JE, Villers A, Redwine EA, Freiha FS, Stamey TA. 1991. Microcarcinoma in the prostate: its association with duct-acinar dysplasia. Hum Pathol 22: 644-652.

Meeker AK. 2018. Cancer telomeres and white crows. Am J Clin Exp Urol 6: 93-100.

Meeker AK, Hicks JL, Platz EA, March GE, Bennett CJ, Delannoy MJ, De Marzo AM. 2002. Telomere shortening is an early somatic DNA alteration in human prostate tumorigenesis. Cancer Res 62: 6405-6409.

Mertz JA, Conery AR, Bryant BM, Sandy P, Balasubramanian S, Mele DA, Bergeron L, Sims RJ 3rd. 2011. Targeting MYC dependence in cancer by inhibiting BET bromodomains. Proc Natl Acad Sci 108: 16669-16674.

Milonas D, Auskalnis S, Skulcius G, Gudinaviciene I, Jievaltas M, Joniau S. 2017. Dutasteride for the prevention of prostate cancer in men with high-grade prostatic intraepithelial neoplasia: Results of a phase III randomized open-label 3-year trial. World J Urol 35: 721-728.

Montironi R, Scarpelli M, Cheng L, Lopez-Beltran A, Zhou M, Montorsi F. 2012. Do not misinterpret intraductal carcinoma of the prostate as high-grade prostatic intraepithelial neoplasia! Eur Urol 62: 518-522.

Morais CL, Han JS, Gordetsky J, Nagar MS, Anderson AE, Lee S, Hicks JL, Zhou M, Magi-Galluzzi C, Shah RB, et al. 2015. Utility of PTEN and ERG immunostaining for distinguishing high-grade PIN from intraductal carcinoma of the prostate on needle biopsy. Am J Surg Pathol 39: 169-178.

Morais CL, Guedes LB, Hicks J, Baras AS, De Marzo AM, Lotan TL. 2016. ERG and PTEN status of isolated highgrade PIN occurring in cystoprostatectomy specimens without invasive prostatic adenocarcinoma. Hum Pathol 55: 117-125. 
L. Trabzonlu et al.

Murphy MJ, Wilson A, Trumpp A. 2005. More than just proliferation: Myc function in stem cells. Trends Cell Biol 15: 128-137.

Nakayama M, Bennett CJ, Hicks JL, Epstein JI, Platz EA, Nelson WG, De Marzo AM. 2003. Hypermethylation of the human glutathione S-transferase-pi gene (GSTP1) $\mathrm{CpG}$ island is present in a subset of proliferative inflammatory atrophy lesions but not in normal or hyperplastic epithelium of the prostate: A detailed study using lasercapture microdissection. Am J Pathol 163: 923-933.

Nakayama M, Gonzalgo ML, Yegnasubramanian S, Lin X, De Marzo AM, Nelson WG. 2004. GSTP1 CpG island hypermethylation as a molecular biomarker for prostate cancer. J Cell Biochem 91: 540-552.

Nelson CP, Kidd LC, Sauvageot J, Isaacs WB, De Marzo AM, Groopman JD, Nelson WG, Kensler TW. 2001. Protection against 2-hydroxyamino-1-methyl-6-phenylimidazo [4,5-b]pyridine cytotoxicity and DNA adduct formation in human prostate by glutathione $S$-transferase P1. Cancer Res 61: 103-109.

O'Shaughnessy JA, Kelloff GJ, Gordon GB, Dannenberg AJ, Hong WK, Fabian CJ, Sigman CC, Bertagnolli MM, Stratton SP, Lam S, et al. 2002. Treatment and prevention of intraepithelial neoplasia: An important target for accelerated new agent development. Clin Cancer Res 8: 314-346.

Park K, Dalton JT, Narayanan R, Barbieri CE, Hancock ML, Bostwick DG, Steiner MS, Rubin MA. 2014. TMPRSS2: $E R G$ gene fusion predicts subsequent detection of prostate cancer in patients with high-grade prostatic intraepithelial neoplasia. J Clin Oncol 32: 206-211.

Perner S, Mosquera J-M, Demichelis F, Hofer MD, Paris PL, Simko J, Collins C, Bismar TA, Chinnaiyan AM, De Marzo AM, et al. 2007. TMPRSS2-ERG fusion prostate cancer: An early molecular event associated with invasion. Am J Surg Pathol 31: 882-888.

Pritchard CC, Mateo J, Walsh MF, De Sarkar N, Abida W, Beltran H, Garofalo A, Gulati R, Carreira S, Eeles R, et al. 2016. Inherited DNA-repair gene mutations in men with metastatic prostate cancer. N Engl J Med 375: 443-453.

Rebello RJ, Pearson RB, Hannan RD, Furic L. 2017. Therapeutic approaches targeting MYC-driven prostate cancer. Genes 8: E71.

Redman MW, Tangen CM, Goodman PJ, Lucia MS, Coltman CA Jr, Thompson IM. 2008. Finasteride does not increase the risk of high-grade prostate cancer: A biasadjusted modeling approach. Cancer Prev Res 1: 174-181.

Ritchie KJ, Henderson CJ, Wang XJ, Vassieva O, Carrie D, Farmer PB, Gaskell M, Park K, Wolf CR. 2007. Glutathione transferase $\pi$ plays a critical role in the development of lung carcinogenesis following exposure to tobacco-related carcinogens and urethane. Cancer Res 67: 9248-9257.

Robinson D, Van Allen EM, Wu Y-M, Schultz N, Lonigro RJ, Mosquera J-M, Montgomery B, Taplin M-E, Pritchard CC, Attard G, et al. 2015. Integrative clinical genomics of advanced prostate cancer. Cell 162: 454.

Ross HM, Kryvenko ON, Cowan JE, Simko JP, Wheeler TM, Epstein JI. 2012. Do adenocarcinomas of the prostate with Gleason score (GS) $\leq 6$ have the potential to metastasize to lymph nodes? Am J Surg Pathol 36: 1346-1352.

Ruijter ET, Miller GJ, van de Kaa CA, van Bokhoven A, Bussemakers MJ, Debruyne FM, Ruiter DJ, Schalken
JA. 1999. Molecular analysis of multifocal prostate cancer lesions. J Pathol 188: 271-277.

Sakr WA, Grignon DJ, Crissman JD, Heilbrun LK, Cassin BJ, Pontes JJ, Haas GP. 1994a. High grade prostatic intraepithelial neoplasia (HGPIN) and prostatic adenocarcinoma between the ages of 20-69: An autopsy study of 249 cases. In Vivo 8: 439-443.

Sakr WA, Macoska JA, Benson P, Grignon DJ, Wolman SR, Pontes JE, Crissman JD. 1994b. Allelic loss in locally metastatic, multisampled prostate cancer. Cancer Res 54: 3273-3277.

Sakr WA, Grignon DJ, Haas GP, Heilbrun LK, Pontes JE, Crissman JD. 1996. Age and racial distribution of prostatic intraepithelial neoplasia. Eur Urol 30: 138-144.

Sánchez-Chapado M, Olmedilla G, Cabeza M, Donat E, Ruiz A. 2003. Prevalence of prostate cancer and prostatic intraepithelial neoplasia in Caucasian Mediterranean males: An autopsy study. Prostate 54: 238-247.

Schröder FH, Hugosson J, Roobol MJ, Tammela TLJ, Zappa M, Nelen V, Kwiatkowski M, Lujan M, Määttänen L, Lilja H, et al. 2014. Screening and prostate cancer mortality: Results of the European Randomised Study of Screening for Prostate Cancer (ERSPC) at 13 years of follow-up. Lancet 384: 2027-2035.

Sedarsky J, Degon M, Srivastava S, Dobi A. 2018. Ethnicity and ERG frequency in prostate cancer. Nat Rev Urol 15: $125-131$

Serefoglu EC, Altinova S, Ugras NS, Akincioglu E, Asil E, Balbay MD. 2013. How reliable is 12-core prostate biopsy procedure in the detection of prostate cancer? Can Urol Assoc J 7: E293-E298.

Sfanos KS, De Marzo AM. 2012. Prostate cancer and inflammation: The evidence. Histopathology 60: 199-215.

Sfanos KS, Yegnasubramanian S, Nelson WG, De Marzo AM. 2017. The inflammatory microenvironment and microbiome in prostate cancer development. Nat Rev Urol 15: $11-24$.

Shah RB, Yoon J, Liu G, Tian W. 2017. Atypical intraductal proliferation and intraductal carcinoma of the prostate on core needle biopsy: A comparative clinicopathological and molecular study with a proposal to expand morphological spectrum of intraductal carcinoma. Histopathology doi: 10.1111/his.13273.

Siegel RL, Miller KD, Jemal A. 2018. Cancer statistics, 2018. CA Cancer J Clin 68: 7-30.

Silberstein JL, Pal SK, Lewis B, Sartor O. 2013. Current clinical challenges in prostate cancer. Transl Androl Urol 2: 122-136.

Sommerfeld HJ, Meeker AK, Piatyszek MA, Bova GS, Shay JW, Coffey DS. 1996. Telomerase activity: A prevalent marker of malignant human prostate tissue. Cancer Res 56: $218-222$.

Taylor BS, Schultz N, Hieronymus H, Gopalan A, Xiao Y, Carver BS, Arora VK, Kaushik P, Cerami E, Reva B, et al. 2010. Integrative genomic profiling of human prostate cancer. Cancer Cell 18: 11-22.

Taylor RA, Toivanen R, Frydenberg M, Pedersen J, Harewood L, Australian Prostate Cancer Bioresou, Collins AT, Maitland NJ, Risbridger GP. 2012. Human epithelial basal cells are cells of origin of prostate cancer, independent of CD133 status. Stem Cells 30: 1087-1096. 
Thompson IM, Goodman PJ, Tangen CM, Lucia MS, Miller GJ, Ford LG, Lieber MM, Cespedes RD, Atkins JN, Lippman SM, et al. 2003. The influence of finasteride on the development of prostate cancer. N Engl J Med 349: 215224.

Thompson JE, van Leeuwen PJ, Moses D, Shnier R, Brenner P, Delprado W, Pulbrook M, Böhm M, Haynes AM Hayen A, et al. 2016. The diagnostic performance of multiparametric magnetic resonance imaging to detect significant prostate cancer. J Urol 195: 1428-1435.

Toivanen R, Mohan A, Shen MM. 2016. Basal progenitors contribute to repair of the prostate epithelium following induced luminal anoikis. Stem Cell Reports 6: 660-667.

Tomlins SA, Rhodes DR, Perner S, Dhanasekaran SM, Mehra R, Sun X-W, Varambally S, Cao X, Tchinda J, Kuefer R, et al. 2005. Recurrent fusion of TMPRSS2 and ETS transcription factor genes in prostate cancer. Science 310: 644-648.

Tosoian JJ, Carter HB, Lepor A, Loeb S. 2016. Active surveillance for prostate cancer: Current evidence and contemporary state of practice. Nat Rev Urol 13: 205-215.

Valdés-Mora F, Stirzaker C. 2018. Epigenetic alterations in primary prostate cancer. In Precision molecular pathology of prostate cancer, molecular pathology library, pp. 193211. Springer, Cham, Switzerland.

Vander Griend DJ, Litvinov IV, Isaacs JT. 2014. Conversion of androgen receptor signaling from a growth suppressor in normal prostate epithelial cells to an oncogene in prostate cancer cells involves a gain of function in $\mathrm{c}-\mathrm{Myc}$ regulation. Int J Biol Sci 10: 627-642.

Vaughn MP, Biswal Shinohara D, Castagna N, Hicks JL, Netto G, De Marzo AM, Speed TJ, Reichert ZR, KwabiAddo B, Henderson CJ, et al. 2011. Humanizing $\pi$-class glutathione $S$-transferase regulation in a mouse model
High-Grade Prostatic Intraepithelial Neoplasia

alters liver toxicity in response to acetaminophen overdose. PLoS ONE 6: e25707.

Voltaggio L, Cimino-Mathews A, Bishop JA, Argani P, Cuda JD, Epstein JI, Hruban RH, Netto GJ, Stoler MH, Taube JM, et al. 2016. Current concepts in the diagnosis and pathobiology of intraepithelial neoplasia: A review by organ system. CA Cancer J Clin 66: 408-436.

Vukovic B, Park PC, Al-Maghrabi J, Beheshti B, Sweet J, Evans A, Trachtenberg J, Squire J. 2003. Evidence of multifocality of telomere erosion in high-grade prostatic intraepithelial neoplasia (HPIN) and concurrent carcinoma. Oncogene 22: 1978-1987.

Wang J, Xie LY, Allan S, Beach D, Hannon GJ. 1998. Myc activates telomerase. Genes Dev 12: 1769-1774.

Wang ZA, Mitrofanova A, Bergren SK, Abate-Shen C, Cardiff RD, Califano A, Shen MM. 2013. Lineage analysis of basal epithelial cells reveals their unexpected plasticity and supports a cell-of-origin model for prostate cancer heterogeneity. Nat Cell Biol 15: 274-283.

Wang ZA, Toivanen R, Bergren SK, Chambon P, Shen MM. 2014. Luminal cells are favored as the cell of origin for prostate cancer. Cell Rep 8: 1339-1346.

Warrick JI, Tomlins SA. 2018. Prostate cancer molecular prognosis. In Precision molecular pathology of prostate cancer, Molecular pathology library, pp. 503-522. Springer, Cham, Switzerland.

Weier C, Haffner MC, Mosbruger T, Esopi DM, Hicks J, Zheng Q, Fedor H, Isaacs WB, De Marzo AM, Nelson WG, et al. 2013. Nucleotide resolution analysis of TMPRSS2 and ERG rearrangements in prostate cancer. J Pathol 230: 174-183.

Wu KJ, Grandori C, Amacker M, Simon-Vermot N, Polack A, Lingner J, Dalla-Favera R. 1999. Direct activation of TERT transcription by c-MYC. Nat Genet 21: 220-224. 


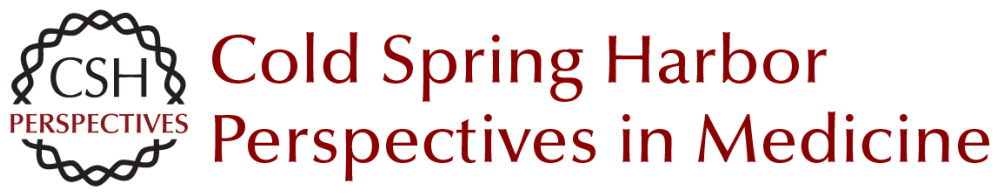

\section{Molecular Pathology of High-Grade Prostatic Intraepithelial Neoplasia: Challenges and Opportunities}

Levent Trabzonlu, Ibrahim Kulac, Qizhi Zheng, Jessica L. Hicks, Michael C. Haffner, William G. Nelson, Karen S. Sfanos, Onur Ertunc, Tamara L. Lotan, Christopher M. Heaphy, Alan K. Meeker, Srinivasan Yegnasubramanian and Angelo M. De Marzo

Cold Spring Harb Perspect Med 2019; doi: 10.1101/cshperspect.a030403 originally published online August 6, 2018

\section{Subject Collection Prostate Cancer}

Anatomic and Molecular Imaging in Prostate Cancer

Eric T. Miller, Amirali Salmasi and Robert E. Reiter

The Epidemiology of Prostate Cancer Claire H. Pernar, Ericka M. Ebot, Kathryn M. Wilson, et al.

Prostate Stem Cells and Cancer Stem Cells Jia J. Li and Michael M. Shen

Prostate Cancer Epigenetics: From Basic Mechanisms to Clinical Implications Srinivasan Yegnasubramanian, Angelo M. De Marzo and William G. Nelson

\section{The Genomics of Prostate Cancer: A Historic Perspective Mark A. Rubin and Francesca Demichelis}

Neuroendocrine Differentiation in Prostate Cancer: Emerging Biology, Models, and Therapies Loredana Puca, Panagiotis J. Vlachostergios and Himisha Beltran

DNA Damage Response in Prostate Cancer Matthew J. Schiewer and Karen E. Knudsen

Transcriptional Regulation in Prostate Cancer David P. Labbé and Myles Brown
New Opportunities for Targeting the Androgen Receptor in Prostate Cancer Margaret M. Centenera, Luke A. Selth, Esmaeil Ebrahimie, et al.

Prostate Cancer Research at the Crossroads Michael M. Shen and Mark A. Rubin

Immunotherapy for Prostate Cancer Nicholas J. Venturini and Charles G. Drake

Molecular Pathology of High-Grade Prostatic Intraepithelial Neoplasia: Challenges and Opportunities Levent Trabzonlu, Ibrahim Kulac, Qizhi Zheng, et al.

Metastases in Prostate Cancer Federico La Manna, Sofia Karkampouna, Eugenio Zoni, et al.

Genetically Engineered Mouse Models of Prostate Cancer in the Postgenomic Era Juan M. Arriaga and Cory Abate-Shen

Molecular Biomarkers in the Clinical Management of Prostate Cancer Aaron M. Udager and Scott A. Tomlins

Metabolic Vulnerabilities of Prostate Cancer: Diagnostic and Therapeutic Opportunities Giorgia Zadra and Massimo Loda

For additional articles in this collection, see http://perspectivesinmedicine.cshlp.org/cgi/collection/ 